figured in plates v to ix of "Collected Papers," they should be found in all such shingle of whatsoever age. None are forthcoming.

If the waves had possessed that power, we should not need to go beyond our beach-girt southern shores or our numerous rivergravels. Challenged long ago to produce an implement of the true platean type from a recent beach, the only specimen that has been put forward as such is one from the beach at Aldborough. I bave examined this specimen carefully. It is a naturally split pebble of the Westleton pebble beds, of which there are millions, entive and split, on the adjacent shore. These, in fact, constitute a very large proportion of the beach itself, and those of them which happened to be split have had their edges chipped and blunted by the pounding they have undergone on the shore, so that to that extent they resemble the one plateau specimen figured, fig. 4 , pl. ii, in the work before mentioned, with the essential exception that whereas the latter often retain the sharp edges which adapted them for scraping, in the former the edges, which are also worn and blunt, were never suited for that purpose. It is, in fact, one of those natural flints which simulate in general outline a worked flint, and in this case $I$ am willing to admit that the simulation of this one simple form of the plateau flint is very good and very deceptive. Scores of such natural forms, imitating even the well-defined shapes of the lance-head Palaolithic implements, have been found in gravel beds.

However, to put the matter to another test, I again repeat the former challenge, and am ready to exchange the two volumes of my "Geology" with any young (or old) dissentient, for half a dozen shore flints (not derived) of any of the platean types figured in the five plates above named.

I have noticed with regret that in discussing the ninor points, the essential and important fact of the plateau implements being possibly the work of the earliest known members of the human stock, has been too much overlooked. While anthropologists have sought for and described the stone implements of modern savages, from the poles to the equator, and speculated on their uses, they have with a few rare exceptions shown an unaccountable indifference, not only in the plateau specimens themselves as specimens, but also an unwillingness to give the subject that attention which alone could settle the question. Here is a problem of high importance with respect to the habits, mode of life, and characters of primitive man, as exhibited in a wonderful profusion of their rude tools, and which is nevertbeless neglected and rejected, not from personal investigation, but on an assumed impossibility and by an abnegation of personal responsibility. Surely the subject is deserving of further investigation. I wait without anxiety the results of my challenge.

Shoreham, KeNT, July $15,1895$. Joseph Prestwich.

DR. CALLAWAY AND METASOMATOSIS.

Sir,-The letter of the Rev. J. F. Blake in last month's Grological Magazine does not call for lengthened comment. 
$\mathrm{He}$ makes it quite clear that in his criticisms of my work at Malvern he had employed the theological, rather than the scientific, method. I had often said that a gradation between two kinds of rock at Malvern proved the derivation of the one from the other; but then I had previously explained, by an accumulation of details, what I meant by a Malvern gradation. Mr. Blake forgot the details, and suggested that I believe any kind of gradation would prove my case. It is possible to involve any author in apparently contrary opinions, if his sentences may thus be detached from their context.

But Mr. Blake goes on to admit that he does not really suppose me to hold the opinion that "if one rock passes into another, one of them is derived from the other," but he does think I argue on the basis of the following: "The character of the stages by which one rock passes into another in the field may suffice of itself to prove that one of them is derived from the other." This is quite another thing, and should have been said at first.

Mr. Blake's use of my illustration of the beef cooking before the fire is rather misleading. The roasting meat undergoes a change, and so do the Malvern rocks during metamorphism. The cook is able to observe the change, and so can the geologist at Malvern: These two points exhaust the analogy as I limited it, and to expand it to cover a special theory of metamorphism is to commit a fallacy in logic.

My critic-perhaps I may say "critics," for Mr. Blake follows in the wake of others-appears to think that no amount of microscopic or ontdoor evidence will suffice to prove the conversion of a diorite into a quartzose gneiss (not "quartz-schist," as Mr. Blake inaccurately" writes). If this opinion be right, we are shut up in eternal darkness on this question, for no other proof is available. Surely, our ignorance of the chemistry of high temperatures and great pressures ought not to be erected into an insuperable bar against the reception of good field-evidence. Are my critics going to wait until earth-forces can be introduced into the laboratory?

WellingtoN, Salop.

C. Callaway.

\section{BOULDERS IN A COPROLITE BED AT STANBBIDGE.}

SiR,-A bed of "coprolites" is now being worked near Stanbridge, in South Bedfordshire, at a spot about half a mile west of the church, just in the angle formed by the roads from Leighton Buzzard and Billington. The bed resembles in many respects the Cambridge Greensand; its thickness varies within short distances, the maximum being about one foot. Fossils are not abundant, but those found belong to species which occur in the Cambridge Greensand. Mr. Jukes-Browne made a fresh survey of the district some ten or eleven years ago, and determined that the bed, which was at that time exposed in some other pits in the neighbourhood, occurred at the base of the Upper Gault, which in this district is very marly, yielding over 50 per cent. of carbonate of lime.

Two boulders of quartzite have recently been found in the 